\title{
Discussion on the Professional Skills Training Strategies of Secretary Majors in Higher Vocational Colleges
}

\author{
Jie Yang \\ Yunnan Jiaotong College, Kunming, Yunnan, 650500
}

Keywords: higher vocational college, secretary major student, professional skills

\begin{abstract}
Higher education has developed from "elite education" to "universal education". The problem of college students' employment is becoming more and more difficult. Therefore, to improve the professional skills of college students, they can be promoted by cultivating professional skills, so that students can have higher professional qualifications. Skills and professional qualities are the important ability of higher vocational students, but also the key content of school teaching. This paper discusses how to cultivate the professional skills of secretarial students by optimizing the curriculum, deepening the cooperation between schools and enterprises, and innovative teaching methods, so that students can quickly adapt to the requirements of the job. Therefore, it is necessary to explore a teaching path that is suitable for the needs of the industry and enterprises, and is also suitable for the development of the profession, and cultivate a batch of students with high-quality compound skills for the society.
\end{abstract}

\section{Introduction}

Most of the secretarial students will go to work in the enterprise after graduation. The professional skills of the students are very high. This requires students to develop their professional skills during their study in the school, so that they will stand in the fierce competition for employment in the future. Professional skills are an important ability of higher vocational students and a key part of school teaching. The teaching of secretarial profession should combine the needs of the society with the development trend of the industry, and highlight the demand-oriented vocational education concept, and effectively strengthen the training of students' professional skills, especially for students in higher vocational colleges, to cultivate their practice. The ability to operate is particularly important. Therefore, it is necessary to explore a teaching path that is suitable for the needs of the industry and enterprises, and is also suitable for the development of the profession, and cultivate a batch of high-quality compound skills for the society.

\section{The Composition of the Professional Skills System of the Secretarial Students}

In addition to mastering solid professional knowledge, students in higher vocational secretarial majors must possess basic qualities and abilities, such as professional ethics, career planning, and humanistic literacy. In addition, secretarial students also should have good communication and language skills, computing application skills, foreign language application ability and strong physical fitness. The above basic qualities and abilities can be combined with the form of the classroom and outside the classroom to educate the students.

The basic qualities and abilities are an important part of the professional skills of the secretarial students. Just like building a building, the foundation can be firmly built and the house built firmly. The basic quality and ability are the foundation, the foundation is firmly played, the basic literacy of the students is available, and the students who are trained can be comprehensive. The education of basic quality and ability can cultivate students with high moral morality, pioneering spirit and innovative spirit. The development of basic qualities and abilities can help the students of secretarial majors to improve their professional skills and enhance their core competitiveness. At the same time, the basic qualities and abilities also reflect the level of a student's ability and the quality of comprehensive literacy. It can enhance students' opportunities in employment, career choice and 
entrepreneurship.

The professional core competencies of secretarial students include: communication skills, language expression skills, document writing skills, coordination skills, organizational skills, meetings and other planning skills. Students in the secretarial majors of higher vocational colleges must learn to exercise their abilities in all aspects and become a "all-rounder." Professional core competence is the core content of students' learning during school, and it is also an important ability that they must have in order to succeed in the future. Professional core competence is an essential skill for students to master, a magic weapon for employment competition, and the key to opening a job after graduation. The professional core competence is the embodiment of the students' comprehensive knowledge of knowledge, ability and skills. It will train students to become the composite skill talents needed by the industry and enterprises.

The students trained in higher vocational colleges are skilled, applied and practical. Therefore, the professional core competence of students is an important part of the professional teaching of high vocational secretarial students, and it is also the main module for students to study at school. The training and orientation of secretarial students should be formulated around the professional goals and the needs of the society for secretarial talents, so as to cultivate students into highly skilled talents with solid theoretical knowledge, skilled hands-on ability and rich practical operation ability.

The ability to expand is to cultivate students' life and survival skills, and to improve the overall quality of students through the development of their ability to expand, so that they can develop in an all-round way. Nowadays, college students are young people of 95. They are the only children at home. They will develop a habit of being pampered when they are young. Because they have sheltered the wind from the wind, they lack the ability to resist stress and frustration. The spirit of down-to-earth, hard work, and unity and cooperation is rarely available.

Nowadays, the society has developed rapidly in all aspects. On the one hand, the post-95 college students have more opportunities and opportunities than ever before. On the other hand, the fierce competition environment has brought them huge challenges. In addition to having a solid foundation for students, In addition to knowledge and professional knowledge, it also needs to have a broad vision, good psychological quality, and sound ideological and moral qualities. Develop their ability to expand while they are at school, provide them with opportunities to practice, learn, and train their will. To develop students' ability to develop their abilities, we must adopt a variety of forms and means to extend the capacity education to the whole process of study, extracurricular activities and life of the secretarial students throughout the university. Implementing the ability education can not only improve the students' psychological quality and ideological and moral quality, but also help students to adapt and compete.

\section{The Cultivation of Professional Skills of Secretarial Students}

The curriculum of the secretarial major in higher vocational colleges should emphasize practicality, skill and professionalism, increase the proportion of practical teaching content, and fully consider the practicality and universality of the secretarial professionals required by contemporary society. Secretarial students need to have three abilities_- “running, doing things, and running meetings". The curriculum should be based on these three abilities to open corresponding courses, and focus on the training and training of professional skills. The professional curriculum must focus on the current trend of social development and the needs of employers for secretarial staff, and strive to form a professional and accurate positioning, and to build a scientific and reasonable curriculum system to cultivate high-skilled talents that meet the requirements of enterprises. The curriculum of the secretarial professional curriculum should be closely matched with the actual work position of the students in the future, so that students can graduate and go to work positions to achieve seamless connection.

After graduating from the secretarial majors in higher vocational colleges, most of them are engaged in secretarial work in enterprises. When the curriculum is set up, the curriculum should be set according to the requirements of modern enterprises for secretarial personnel, so as to arrange 
the teaching content scientifically and reasonably, so that the graduates of secretarial majors Can be consistent with the needs of the personnel of the employer, to achieve graduation and employment. The training objectives and orientation of higher vocational colleges are different from those of undergraduate colleges. The study of theoretical knowledge is not like the undergraduate course. The same is true for the teaching of secretarial majors. In the course setting, most of the theoretical courses cannot be arranged. Some courses should be merged and streamlined (for example, the etiquette class and the communication skills class can be combined), otherwise the students will have more theoretical knowledge. Therefore, the curriculum should be combined with the actual situation of the industry and enterprises, and timely understand the needs of the industry and enterprises, to rationally carry out the curriculum system setting, so that the students who have been trained can achieve professional skills and find a suitable job.

Higher vocational students should pay attention to practical hands-on ability and avoid purely theoretical teaching in teaching. The teacher teaches the students, and the content should be highly practical, starting from the development of students' operational ability and hands-on ability. In addition to teaching theoretical knowledge, teachers must pay attention to the cultivation and education of students' practical ability, and guide students to transform their theoretical knowledge into skills and abilities.

The training objectives of higher vocational colleges are different from those of undergraduate colleges. Therefore, the teaching of practical training courses is very important for students because it makes students become knowledgeable, skilled and will operate. High-skilled and practical talents, so the teaching of practical training courses cannot be in the form. It is necessary to convert knowledge points into skill points. In the teaching of practical training courses, we should pay attention to standardization and systemization, so that students can gain direct experience and ability. Class teaching is not an aid to theoretical teaching. Its weight is the same as that of theoretical teaching.

The secretarial profession is a profession that attaches importance to practical teaching. The training of the practical training course allows students to check the professional knowledge they have learned. The second is to test the knowledge they have learned in the practice of practical training and to put knowledge into it. Convert to your own abilities. Therefore, the teaching of practical training is very important, so that the students who have cultivated have both certain theoretical knowledge and mastered practical ability. Graduates can quickly adapt to work in the future.

It is necessary to form a deep cooperation between schools and enterprises, through school-enterprise cooperation, organize students to go deep into the enterprise, understand the organizational structure, culture, management mode, business model of a company, etc. Students can learn a lot of books in the process of deepening the enterprise. In the process of school-enterprise cooperation, schools should make full use of the platform of the enterprise to communicate with the enterprise to discuss and formulate personnel training programs, teaching plans, training plans, etc., and let the enterprises participate in the school to further realize the school-enterprise In-depth cooperation, the formation of school training is the talent that enterprises need.

School-enterprise cooperation can provide students with many practical and internship opportunities, which can enrich students' professional knowledge and professional ability. In the practice and internship of the enterprise, students are allowed to learn a lot of knowledge that can't be learned in the school, so that the students' organizational ability, language expression ability, coordination ability and other aspects can be exercised. Students who have graduated from secretarial studies, they are not engaged in the office every day after graduation. Sometimes they have to go to the production line of the enterprise and the first-line sales department. Therefore, it is necessary to understand the management mode and operation mode of the whole enterprise. . During the period of study, students can have the opportunity to go deep into the enterprise to study and practice. Through the various internship positions provided by the company, they can exercise their own abilities and test their professional knowledge and professional ability. Students can go to 
work in the future. Adapt to the working environment quickly.

The teaching method of classrooms in higher vocational colleges cannot be purely theoretical teaching. It is necessary to adopt a variety of teaching methods, such as case teaching method, situation teaching method and on-site teaching method. Teachers should adopt a variety of teaching methods, because high-level students have weak theoretical knowledge and poor learning, and can not adopt a single old theoretical teaching, so they must innovate teaching methods. As a secretarial major, teaching can not be taught in the traditional teaching mode. It is necessary to teach through a variety of teaching methods, so that it will receive good teaching effects. For example, the situational teaching method is to create different scenarios in the classroom teaching process. Let students learn knowledge and training skills in different simulation scenarios (such as: simulation reception scene, simulation paper processing, simulation conference preparation, etc.).

The study of knowledge cannot be a simple lecture. It is necessary to use a variety of teaching methods to develop students' ability to understand, use and think independently. In addition, there are other teaching methods such as demonstration method, case teaching method, flipping classroom method, practice operation method, etc., and using various teaching methods, students can gradually reach the analogy of learning and learn from others, and improve students' knowledge and skills.

Through innovative teaching methods, students can learn knowledge and skills in a diverse and flexible learning environment, so that students' ability in all aspects will be improved, and a solid professional skills foundation will be laid for students' employment and career choice.

\section{Conclusion}

Higher education has developed from "elite education" to "universal education". The employment problem of college students has become more and more difficult. Therefore, it is necessary to improve the professional skills of college students to enhance their employability, so that students can have higher professional skills and professional qualities. . This paper explores how to cultivate the professional skills of secretarial students from the perspectives of optimizing curriculum, in-depth cooperation between schools and enterprises, and innovative teaching methods, so that students can quickly adapt to the needs of their jobs after graduation. The secretarial profession in higher vocational colleges trains skilled and practical talents, not research or theoretical talents. Therefore, in the process of cultivating students, we should be guided by the professional skills of the secretarial profession, aiming at the ability and skills, so that students can master the basic requirements and norms of secretarial work before they leave the school, and can cope with it. Handle the daily affairs of the office.

\section{References}

[1] Zhang Wei. An Empirical Study on the Training Mode of Vocational Core Competence of Higher Vocational Students [J]. Vocational Education Forum, 2012, (8): 72-74.

[2] Zhang Tao. Analysis on the Construction of Professional Core Competence of Higher Vocational Talents [J]. Heilongjiang Higher Education Research, 2010, (5): 90-93.

[3] Zheng Qingqing. Thoughts on how to improve the professional ability of secretarial students [J]. Employment, 2012, (8): 55-56. 